\author{
Mariusz Wesolowski \\ dr inż. \\ Zakład Lotniskowy \\ Instytut Techniczny Wojsk Lotniczych \\ mariusz.wesolowski@itwl.pl
}

\title{
Adam Poświata
}

dr inż.

Zakład Lotniskowy

Instytut Techniczny Wojsk Lotniczych

adam.poswiata@itwl.pl

DOI: 10.35117/A_ENG_17_11_04

\section{Airfield pavements as an element of critical infrastructure in the airport safety management process}

\begin{abstract}
Contemporary planes moving with high velocity and loads require well design, properly building and maintenance airfield pavements. The main objective of this factors is provide safety conditions for moving planes. Technical condition airfield pavements has a direct impact on the safety performance of air operations. This forces the need to have full knowledge of their condition, which will be allowed to take appropriate decisions to ensure their safe operation. In this paper the issues connected with the assessment of airfield pavements health, such as: methodology assessment of the degradation degree, bearing capacity, evenness, roughness and Polish Standards in force and Air Force Institute of Technology developed procedures are presented. Moreover, possible operating danger and realize research work for safety improvement are presented.
\end{abstract}

Keywords: Airfield pavements; Critical infrastructure; Safety; Air operations; Aircraft

\section{Introduction}

The safety problem of performing air operations in the aviation training process will be valid as long as there is aviation, both civil and military. Ensuring safety was, is and will be one of the most important problems in the functioning and development of aviation. The safety of flight operations is affected by all elements involved in this process, which can be summarized in three groups, i.e. a man (flight attendants, aircraft maintenance personnel, air traffic control personnel, airport equipment personnel), aircraft (airplanes, helicopters and other flying objects) and surroundings (aerodromes, including airport pavements and airspace).

The priority task of the airport service is to ensure safe operation of airport pavements by aircraft. The airport pavement in the aspect of the aviation safety training system is characterized by the determination of its technical condition. The Aerospace Institute of the Air Force Institute (ITWL) is for a long time an extremely important cell supporting the activities of airport services in the Polish Armed Forces and in civil aviation. The employees of the ITWL Airport Department supervise and advise technology on modernization, renovation and other works carried out at airport facilities, including consulting and conducting expert reports. Diagnostic tests conducted during the process of operation of airport pavements allow determining their current technical condition, and in the case of newly built surfaces, allow to assess the quality of the constructed structure. 
Knowledge about airport issues, supported by over 60 years of experience gained in the implementation of investment and repair tasks on military and civilian airport facilities, contributed to the development by ITWL of many normative documents and guidelines that were and are still widely used by representatives of both military, and civilian airport service, i.e.:

- NO-17-A204:2015 Airport concrete surfaces. Requirements and test methods for cement concrete pavement [6],

- NO-17-A200:2017 Airport surfaces - Asphalt concrete pavements - Requirements and tests [5],

- NO-17-A500:2016 Airport and road surfaces. Load tests [7],

- NO-17-A501:2015 Airport surfaces - Roughness tests [8],

- NO-17-A502:2015 Airport surfaces - Equality studies [9],

- NO-17-A503:2017 Airport pavements - Darni and land airport pavements - Load capacity tests [10].

\section{Assessment of technical condition of airport surfaces}

Currently used aircraft require airport pavements well designed, properly built and operated. The basic type of airport surfaces are cement concrete pavements, which now and in the long term will be subject to further modifications and maintenance measures. However, it should be noted that more and more often natural airport surfaces are also used in the aviation training process.

From the finished airport surface, good adhesion of the aircraft wheels to the surface, ability to surface water drainage, high frost resistance and resistance to deicing agents used for winter maintenance as well as high compressive and bending strength are required. In addition, the new and already existing airport pavement should meet certain requirements in terms of load capacity, equality, roughness and durability, in particular for its subsurface layer.

Monitoring the technical condition of the airport surfaces is extremely important in the aspect of ensuring the safety of flight operations, that is also conducting flight training. In order to assess the technical condition of artificial airport pavements, newly built and already in operation, diagnostic tests should be carried out to determine such parameters as:

- degradation of the surface (surface condition based on the inventory),

- load capacity,

- equality,

- roughness,

- peel strength (durability of the surface layer)).

However, in the case of natural airport surfaces, the parameter determining its technical condition is the load capacity.

\section{Degradation of airport surfaces}

Due to the destructive processes occurring in cement concrete and asphalt concrete and the damage occurring in connection with this, it is essential to perform periodic inspections of the technical condition of airport pavements, so-called damage inventory. All kinds of damage pose a threat to the safety of moving aircraft. Below, Figure 1 shows the components of the assessment process for degradation of airport pavements. 


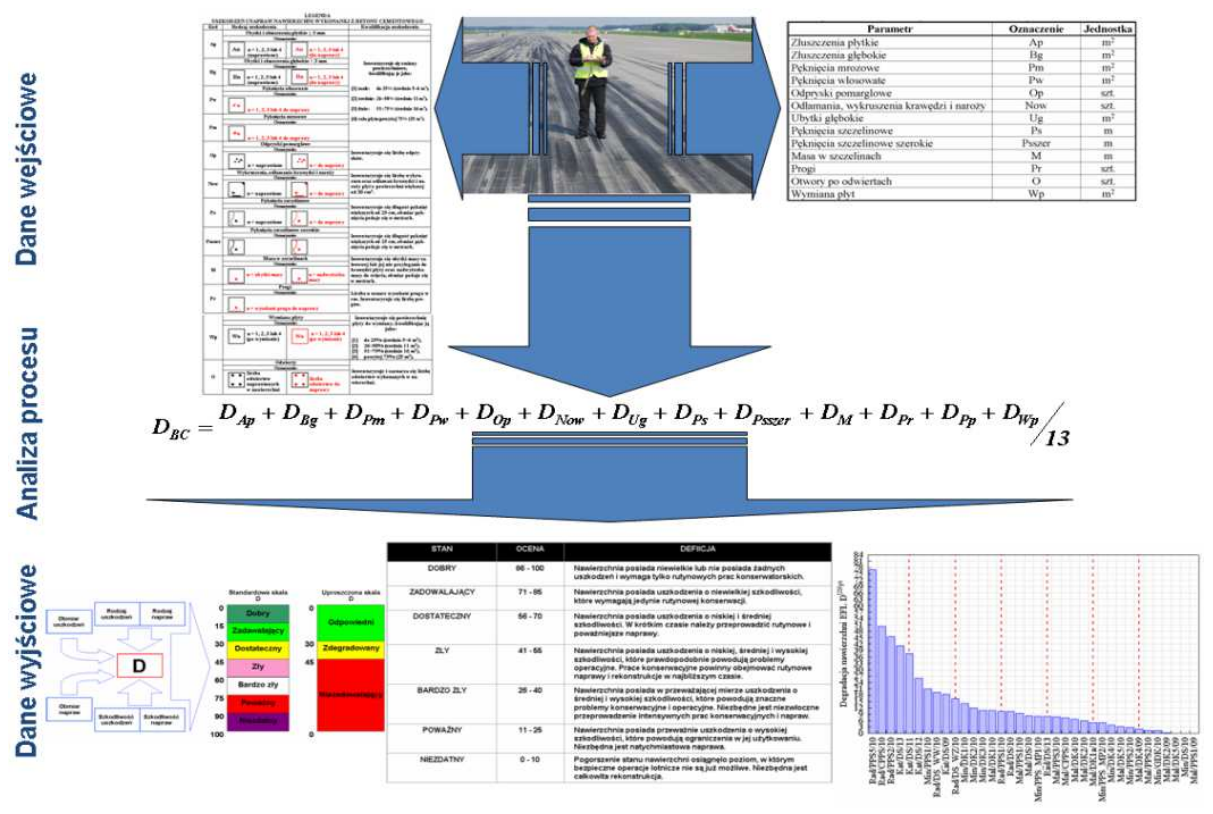

1. The process of assessing the degradation of airport pavements [3]

Inventory of damage to airport pavements is performed directly on the site, updating and registering the damage condition for each functional element of the airport (EFL) and individual boards. Usually, a visual method is used. Inventory is carried out on standard sleepers, in a "plate" system, i.e. every CD is inventoried at the airport (usually $5 \times 5 \mathrm{~m}$ ). The position of each plate is indicated by means of numbers, which are adopted in accordance with the numerical markings printed on the individual sheets. Inventory both existing damage and damaged repaired. Such a "double" inventory allows not only to determine the size of damage at the airport but also allows the determination of a general indicator of object degradation.

\section{Bearing capacity}

Assessment of the load bearing capacity of airport pavements is performed in accordance with the requirements of the norms NO-17-A500: 2016 [7], ICAO Annex 14 to the Convention on International Civil Aviation [12] and Aerodrome Design Manual Part 3, Pavements [2].Assessment of load capacity of airport pavements is carried out using the ACN-PCN (Aircraft Classification Number - Pavement Classification Number) method described in Annex 14 of the International Civil Aviation Organization. This method expresses the relationship between the impact of the aircraft on the surface and the reaction of the surface to the generated loads. This method takes into account: type of airport surface, ground category, maximum pressure in the aircraft's tires and the method of determining its bearing capacity.

The heavyweight deflectometer type HWD (Heavy Weight Deflectometer) is used to test the load-bearing capacity of airport pavements. As part of the tests, elastic deflections of the pavement are made, on the basis of which the PCN load factor value is determined (eg PCN 48 / R / B / X / T) and/or the permitted number of flight operations for the type of calculation aircraft accepted. In order to carry out a full analysis of the load-bearing capacity of the assessed airport pavement, its structure is identified by taking samples in the form of core bores, which are then subjected to strength tests in laboratory conditions. The course of spring deflection measurements of the airport pavement is shown in Figure 2. 


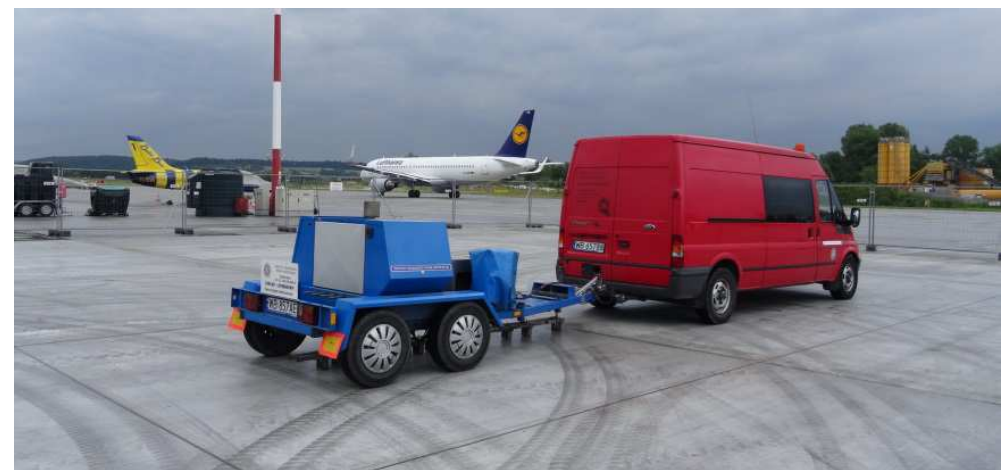

2. Measurement of elastic deflections of airport pavement

As mentioned, the results obtained during the ACN-PCN bearing capacity test can be presented in the form of the PCN load capacity index and/or the determined admissible total number of aircraft operations, which are determined for a given number of repetitions $\mathrm{N}$. The number of permissible repetitions is calculated depending on the adopted calculation model the assessed construction of the airport pavement. For rigid constructions made of cement concrete, the following formula is applied resulting from the criterion of allowable stresses [4]:

$$
N=\left[\frac{R_{z g}}{\sigma} \times\left(\frac{E}{30000}\right)^{1.3}\right]^{(-1 /-0.233)} \times 10^{4}
$$

where:

$R_{z g}$ - tensile strength of concrete when bending [MPa],

$\sigma-$ tensile stress at bending determined at the bottom of the concrete slab [MPa],

$E$ - elasticity modulus of concrete [MPa].

On the other hand, for susceptible surfaces made in the asphalt concrete technology, the following formula should be used, resulting from the criterion of permissible deformations [4]:

$$
N=\left[\frac{R_{z g}}{\sigma} \times\left(\frac{E}{160}\right)^{1.23}\right]^{(1 / 0.173)} \times 10^{4}
$$

where:

$R_{z g}$ - tensile strength when bending the substrate [MPa],

$\sigma$-tensile stresses when bending determined for the ground [MPa],

$E$ - soil rigidity modulus [MPa].

In connection with the above, it should be stated that there is a strict dependence of the PCN load capacity on the number of permitted air operations in determining the load-bearing capacity of airport pavement structures using the ACN-PCN method.

Due to the fact that aeronautical training has recently been intensified with the use of natural airport pavements, ITWL has developed a defense standard NO-17-A503: 2017 Surface pavements - Darni and land airport pavements - Load capacity tests [10]. Air operations using this type of surface are already performed, inter alia, at the military airport Powidz, which is shown in Figure 3. 


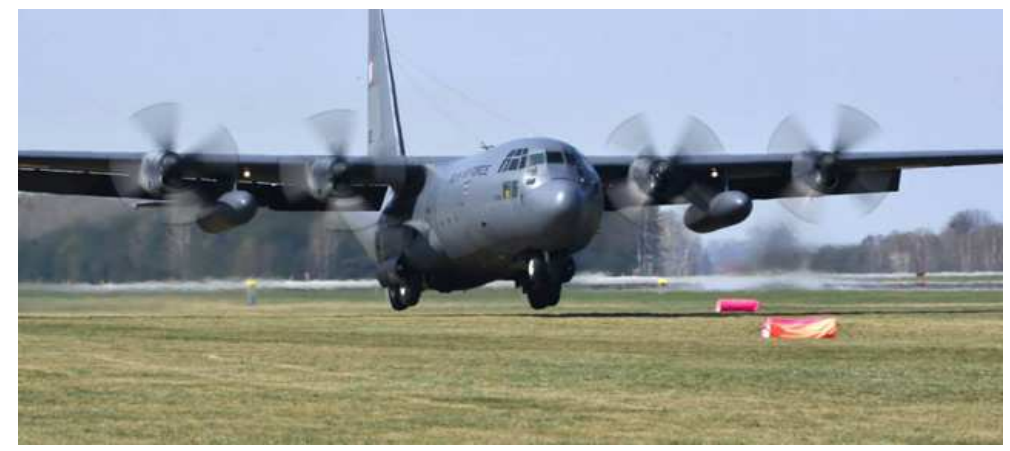

3. View of turf airport pavement in the aviation training process

Tests on the load capacity of turf and ground airport pavements should be performed for: Work Runway or Emergency Runway, Side Safety Belts and Safety Seatbelts. The loadbearing capacity of natural airport pavements is expressed in the Californian load capacity index CBR, which is calculated according to the formula:

$$
C B R=\frac{292}{D C P^{1,12}}
$$

where:

$C B R$ - Californian load index, in percent,

$D C P$ - probe cone hollow per one stroke, in millimeters.

\section{Roughness}

The state of roughness of airport pavements is extremely important for the safety of air operations. Roughness tests of airport pavements are carried out in accordance with the requirements of defense standard NO-17-A501: 2015 [8] and the requirements of Annex 14 to the Convention on International Civil Aviation [12] and Advisory Circular No: 150 / 5320$12 \mathrm{C}$ [1]. A view of the friction coefficient measurements made on the concrete airport pavement is shown in the illustration 4.

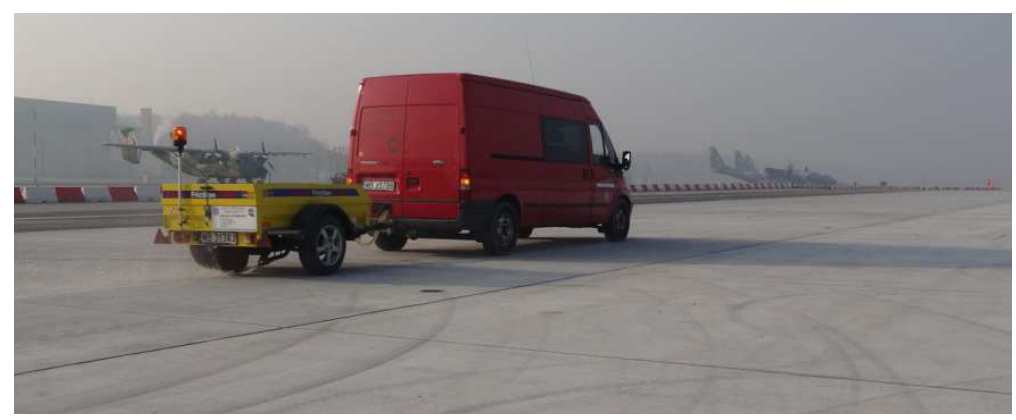

4. View of friction coefficient measurements on a concrete airport pavement

The standard [8] discusses the methodology for testing the roughness of airport pavements, specifies the requirements for the equipment used for measurements in field conditions and presents criteria for assessing the roughness of airport pavements (average values of required friction coefficients) depending on the type of measuring device and measurement conditions used (measurement speed, type of measuring tire, measurement with or without water).

The required mean coefficients of friction were determined for three compartments, i.e. for designed, new airport pavements, for used and/or subject to planning renovation works and minimum (limit). For example, the required friction coefficient values for airport 
pavements evaluated using a measuring device ASFT on the trailer The T-10 at a measuring speed of $65 \mathrm{~km} / \mathrm{h}$ is as follows [8]:

- for designed, new airport pavements - 0.70,

- for maintenance works used and/or being planned - 0.50,

- minimal (limit) - 0,40.

\section{Equality}

The tests of equality of airport pavements are carried out in accordance with the requirements of defense standard NO-17-A502: 2015 [9], using a modernized planograph

$\mathrm{P}-3 \mathrm{z}$, which is shown in the illustration 5.

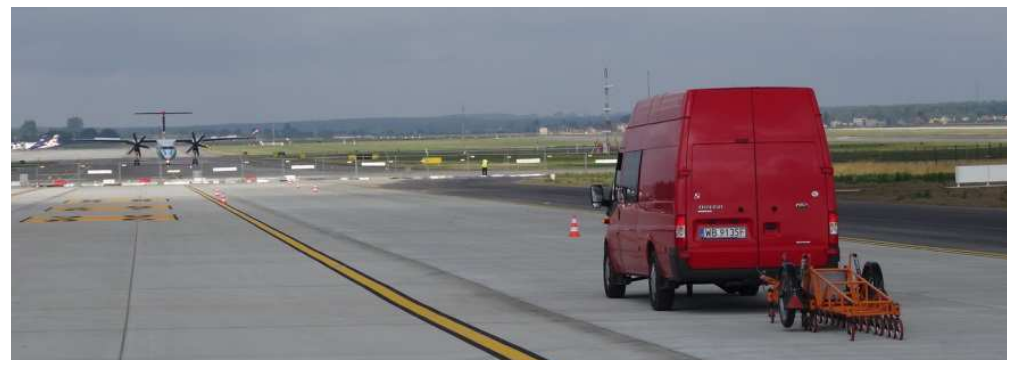

5. A view of equality measurements on a concrete airport pavement

The condition of equality determines not only the comfort of movement on the airport pavement but also affects the size of dynamic impacts on the surface. Obtaining the required equality is also a condition for the efficient and rapid discharge of rainwater from airport pavements. Even on small unevenness of the surface can create water stagnation, which in winter worsens the conditions of traffic safety.

The equality of airport pavements should meet the criteria determined by the level of defectiveness. Defects are understood as a percentage measure of the number of exceedances of inequalities accepted in the standard as acceptable. In accordance with the abovementioned standard, on the basis of the defectiveness criterion W (\%) - the following assessments are taken [9]:

- very good $\quad-\mathrm{W} \leq 5 \%$,

- $\operatorname{good} \quad-5 \%<\mathrm{W} \leq 10 \%$,

- sufficient $\quad-10 \%<\mathrm{W} \leq 20 \%$,

- unsatisfactory - $20 \%<\mathrm{W} \leq 50 \%$,

- insufficient $-\mathrm{W}>50 \%$.

\section{Peel strength}

The defensive standard NO-17-A204: 2015 [6], developed by ITWL, also provides for checking the peel strength for the surface layer of the airport pavement. The durability of the surface layer is important from the point of view of ensuring the safety of performing air operations in the aspect of sucking foreign bodies by aircraft - FOD (Foreign Object Damage) [11]. An illustration of this is a direct threat to the safety of aircraft, their crew, and passengers related to this issue 6. 


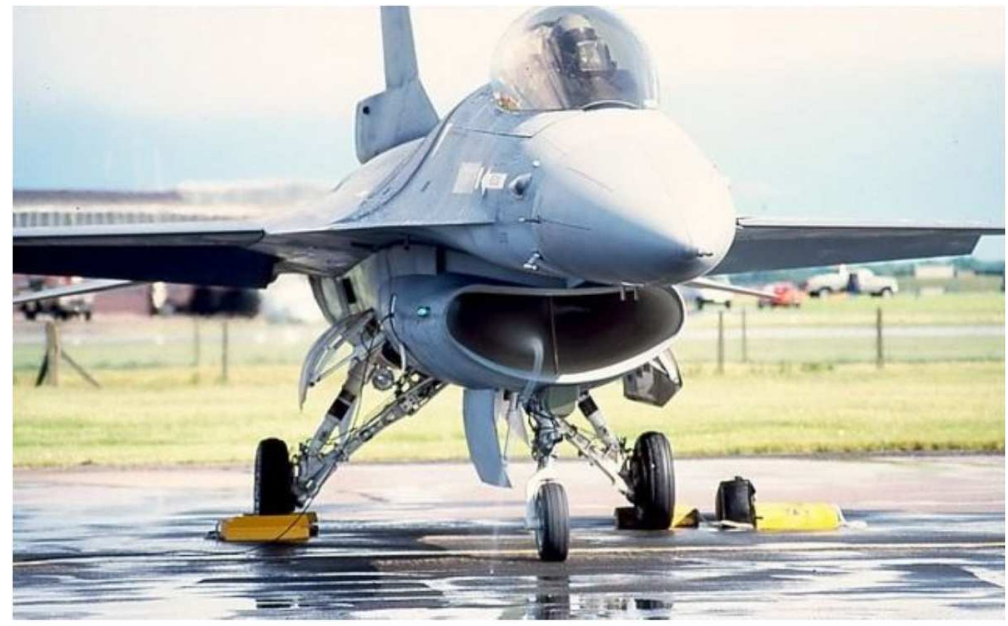

6. View of the vortex in front of the intake sucking from the airport pavement

Criteria for assessing the peel strength of the surface layer of an airport concrete surface are as follows [6]:

- average strength should not be less than $2.0 \mathrm{MPa}$, but the value of a single measurement should not be less than $1.8 \mathrm{MPa}$ (age of the surface up to 10 years),

- average strength should not be less than $1.8 \mathrm{MPa}$, but the value of a single measurement should not be less than 1.6 MPa (age of the surface over 10 years)).

\section{Summary and Conclusions}

Airport pavements are a particularly important element of critical infrastructure that is part of the ground part of the maneuvering field, intended for traffic, stopping and servicing aircraft. Their main and at the same time the most important task is the safe transfer of utilitarian loads from moving or standing aircraft on them, as well as neutralizing thermal and forced natural loads and transferring these total loads to the ground. The complex process of impact of aircraft on the surface requires its adaptation to the abovementioned complicated tasks.

Achieving a high technical level for the construction of airport pavements is a must and it must be a continuous process that uses contemporary design and technological achievements. Improving this process is the task of airport services. The process of the durability of airport pavings is part of this process and, therefore, work is underway, resulting in new material proposals and diagnostic methods for assessing the technical condition. An important matter for the correct procedure of maintaining airport pavements at a high and safe technical level are the methods of technical diagnostics and developed methods of the IT database on surfaces and airport infrastructure. Airport maintenance processes are connected with sufficiently high resources for this purpose. Because airport surfaces and complex technical infrastructure systems of airports are an essential element of air transport, the costs incurred are a value hardly comparable with the safety of this type of communication.

\section{Source materials}

[1] Advisory Circular 150/5320-12c, FAA.

[2] Aerodrome Design Manual Part 3, Pavements, ICAO, Doc-9157-AN/901.

[3] Barszcz P., Wesołowski M.: System oceny stanu technicznego nawierzchni lotniskowych jako element procesu zarządzania jakościa w lotnictwie wojskowym, Logistyka 6/2014.

[4] Blacha K., Wesołowski M.: Zależność wskaźnika nośności PCN od liczby operacji lotniczych przy określaniu nośności konstrukcji nawierzchni lotniskowych metodą ACNPCN. Logistyka nr 6/2014. 
[5] NO-17-A200:2017 Nawierzchnie lotniskowe - Nawierzchnie z betonu asfaltowego Wymagania i badania.

[6] NO-17-A204:2015 Lotniskowe nawierzchnie betonowe. Wymagania i metody badań nawierzchni z betonu cementowego.

[7] NO-17-A500:2016 Nawierzchnie lotniskowe i drogowe. Badania nośności.

[8] NO-17-A501:2015 Nawierzchnie lotniskowe - Badania szorstkości.

[9] NO-17-A502:2015 Nawierzchnie lotniskowe - Badania równości.

[10] NO-17-A503:2017 Nawierzchnie lotniskowe - Darniowe $i$ gruntowe nawierzchnie lotniskowe - Badania nośności.

[11] Wesołowski M., Poświata A.: Bezpieczeństwo i niezawodność wykonywania operacji lotniczych na obiektach lotniskowych Sit Zbrojnych RP, Konferencja Naukowa „Współczesne problemy logistyki lotnictwa. Teoria i praktyka”, Dęblin 2015.

[12] Załącznik 14 ICAO do Konwencji o międzynarodowym lotnictwie cywilnym, Lotniska Tom I-Projektowanie i eksploatacja lotnisk, wydanie 6, lipiec 2013. 